\title{
KAJIAN SEKTOR PERTANIAN TERHADAP PEREKONOMIAN DI KABUPATEN MINAHASA UTARA
}

\author{
Kevin John Manoppo \\ Benu Olfie. L. S \\ Lyndon Pangemanan
}

\begin{abstract}
This study aims to determine the size of the contribution to the agricultural sector and to determine whether the agricultural sector became the basic sector and any agricultural subsector that became the base sector. The data used were collected from Central Bureau of Statistics of North Minahasa District, Central Statistics Agency of North Sulawesi, North Minahasa BAPPEDA. The data is then analyzed by calculating how much the contribution of agriculture sector to the economi of North Minahasa District, LQ, and economic growth rate. The results showed that the contribution of the agricultural sector tends to decrease in the period 2010-2015, but the agricultural sector is still the sector that has the largest contribution in PDRB Kabupaten Minahasa Utara. Average growth rate of agriculture sector during the period of 2010-2015 was amounted to 4.48\% the calculation of $L Q$ indicates that the agricultural sector was still the base sector in North Minahasa Regency and agriculture sub-sector which is the base sub-sector was horticulture and the others, annual plantation sector such as the livestock sub sector and fishery sub-sector.
\end{abstract}

Keywords: sector and sub-sector of agricultural, the basic sector, economic growth rate, North Minahasa

\begin{abstract}
ABSTRAK
Penelitian ini bertujuan untuk mengetahui besarnya kontribusi sektor pertanian, serta mengetahui apakah sektor pertanian menjadi sektor basis dan sub sektor pertanian apa saja yang menjadi sektor basis. Data yang digunakan dikumpulkan dari Badan Pusat Statistik Kabupaten Minahasa Utara, Badan Pusat Statistik Sulawesi Utara, BAPPEDA Minahasa Utara. Data kemudian dianalisis dengan menghitung berapa besar kontribusi sektor pertanian terhadap perekonomian Kabupaten Minahasa Utara, LQ, serta tingkat pertumbuhan ekonomi. Hasil penelitian menunjukan kontribusi sektor pertanian cenderung mengalami penurunan dalam kurun waktu tahun 2010-2015, namun sektor pertanian masih merupakan sektor yang memiliki kontribusi terbesar dalam PDRB Kabupaten Minahasa Utara. Laju pertumbuhan rata-rata sektor pertanian dalam kurun waktu tahun 2010-2015 sebesar 4,84\%. Hasil perhitungan LQ menunjukkan sektor pertanian masih merupakan sektor basis di Kabupaten Minahasa Utara serta sub sektor pertanian yang merupakan sub sektor basis adalah sub sektor tanaman hortikultura tahunan dan lainnya, sub sektor perkebunan tahunan, sub sektor peternakan, dan sub sektor perikanan.
\end{abstract}

Kata kunci: sektor dan subsektor pertanian, sektor basis, pertumbuhan ekonomi, Minahasa Utara 


\section{PENDAHULUAN}

\section{Latar Belakang}

Era globalisasi sekarang ini kota-kota besar maupun kawasan-kawasan strategis di Indonesia akan berkembang menjadi sebuah sistem kewilayahan dimana satu sama lain akan terkait dalam suatu sitem pengembangan dan saling ketergantungan, kota-kota dan wilayah lain di Indonesia akan melaksanakan pembangunan berkelanjutan harus mengantisipasi peluang dan tantangan yang akan timbul oleh adanya kebijakan regionalisasi (Riyadi, 2005). Secara filosofi suatu proses pembangunan dapat diartikan sebagai upaya yang sistematik dan berkesinambungan untuk menciptakan keadaan yang dapat menyediakan berbagai alternatif yang sah bagi pecapaian aspirasi setiap warga yang paling humanistik. Dengan perkataan lain proses pembangunan merupakan proses memanusiakan manusia, pada dasarnya pembangunan merupakan salah satu wujud dari tugas pelayanan yang di laksanakan pemerintah dalam rangka memenuhi kebutuhan masyarakat. Pembangunan nasional yang diarahkan pada pembangunan daerah, berdasarkan UU no 23 Tahun 2014 tentang pemerintahan daerah, pada dasarnya adalah untuk memacu pemerataan pembangunan dan meningkatkan kesejahteraan rakyat. Dimana peran serta pemerintah dan masyarakat sangat penting sekali dalam pendayagunaan potensi daerah secara optimal dan terpadu, sehingga upaya pemerataan pembangunan diseluruh tanah air mulai dari daerah maju, berkembang, terpencil perlu untuk ditingkatkan demi tercapainya pembangunan wilayah secara nasional. Pembangunan harus dipandang sebagai suatu proses multidimensional yang mencakup berbagai perubahan mendasar atas struktur sosial, sikap-sikap masyarakat, dan institusi nasional, di samping tetap mengejar akselerasi pertumbuhan ekonomi, penanganan ketimpangan pendapatan, serta penanganan kemiskinan. Jadi pembangunan suatu negara dapat dikatakan baik tidak hanya dilihat dari pertumbuhan ekonominya yang semakin meningkat, tetapi juga dilihat dari aspek-aspek lain yang di miliki. Secara langsung dapat di lihat dari bagaimana masyarakat dapat menikmati hasil-hasil pembangunan dengan mudah.
Menurut Rustiadi (2006), wilayah dapat di definisikan sebagai unit geografis dengan batas-batas spesifik tertentu, di mana komponen-komponennya memiliki arti didalam mendeskripsikan dan pengelolaan sumber daya pembangunan. Istilah wilayah menekankan interaksi antara manusia dengan sumberdayasumberdaya lainnya yang ada di dalam suatu batasan unit geografis tertentu. Pengembangan Wilayah menurut Rustiadi dkk, (2011), adalah pengembangan fungsi tertentu dari suatu unit wilayah, mencakup fungsi sosial, ekonomi, budaya, politik, maupun pertahanan dan keamanan yang mempunyai cakupan keterkaitan antar kawasan. Salah satu tujuan pengembangan wilayah adalah pemerataan kesejahteraan antar wilayah. Kesejahteraan suatu wilayah dapat dilihat melalui tingkat pertumbuhan ekonomi wilayahnya. Pertumbuhan ekonomi wilayah adalah pertambahan pendapatan masyarakat secara keseluruhan yang terjadi di wilayah tersebut, Pembangunan wilayah yang ditinjau dari aspek ekonomi harus menjadi prioritas utama dalam menggerakan ekonomi nasional. Perencanaan yang baik dan proses yang terarah dapat menciptakan perekonomian yang stabil dan merangsang pertumbuhan ekonomi.

Pembangunan ekonomi daerah bertujuan meningkatkan taraf hidup dan kesejahteraan rakyat didaerah melalui pembangunan yang serasi dan terpadu baik antar pembangunan sektoral dengan perencanaan pembangunan oleh daerah yang efisien dan efektif menuju tercapainya kemandirian daerah dan kemajuan yang merata secara keseluruhan. Sedangkan pembangunan sektor ekonomi merupakan proses untuk mengubah suatu keadaan supaya lebih baik dengan tujuan untuk meningkatkan pendapatan, kesempatan kerja, dan kemakmuran masyarakat (Sukirno, 2005). Sektor ekonomi suatu wilayah dapat di bagi menjadi 2 golongan, yaitu sektor basis dimana kelebihan dan kekurangan yang terjadi dalam proses pemenuhan kebutuhan tersebut menyebakan mekanisme ekspor dan impor antar wilayah.

Sedangkan sektor non-basis sektor dengan kegiatan ekonomi hanya melayani pasar di daerah sendiri dan kapasitas ekspor daerah belum berkembang. Untuk mencapai hasil pembangunan ekonomi yang diharapkan, maka 
perlu pula dilakukan perencanaan dan perkiraan terhadap setiap sektor maupun secara agregatif. Perlu pula dilakukan penekanan terhadap setiap sektor tertentu sehingga dapat dimungkinkan terjadi perubahan dalam struktur ekonomi. Hal ini dapat dilakukan untuk meningkatkan laju pertumbuhan dan kontribusi satu sektor tertentu terhadap pembentukan PDRB yang tentunya akan menurunkan kontribusi dari sektor yang lainnya dan dengan demikian dapat diketahui pula mana yang menjadi sektor unggulan dari daerah tersebut. Kabupaten Minahasa Utara mempunyai potensi sumber daya alam dan sumber daya manusia yang baik. Apabila potensi tersebut dimanfaatkan maka akan sangat membantu pembangunan perekonomian. Terlebih lagi dengan adanya otonomi daerah, Kabupaten Minahasa Utara harus mampu memacu pemerataan pembangunan dan meningkatkan kesejahtraan rakyat, dimana peran dari pemerintah dan masyarakat sangat mempengaruhi terhadap pendayagunaan potensi yang di miliki secara optimal dan terpadu.

Kabupaten Minahasa Utara merupakan suatu wilayah yang sedang berkembang dan memacu pembangunan di segala aspek bidang, sambil mempelajari potensi-potensi yang dimiliki oleh Kabupaten Minahasa Utara. Salah satu potensi yang dimiliki oleh Kabupaten Minahasa Utara adalah pada sektor pertanian. Menurut data PDRB tahun 2010-2015 sektor pertanian masih memiliki PDRB yang tertinggi. Ini berarti sektor pertanian masi memilki kontribusi yang terpenting dalam membentuk membentuk PDRB di Kabupaten Minahasa Utara, sehingga sangat penting untuk mengevaluasi kemampuan daerah dalam merencanakan pembangunan daerah, sehingga Kabupaten Minahasa Utara bisa mendaptakan suatu data yang akurat. Keberhasilan pembangunan suatu daerah berkaitan erat dengan perencanaan yang dilakukan, Sehingga perlu mempelajari dan menganalisis sektor potensial daerah di Kabupaten Minahasa Utara.

\section{Perumusan Masalah}

Penelitian ini fokus pada beberapa masalah diantaranya:

1. Bagaimanakah kontribusi sektor pertanian terhadap perekonomian di Kabupaten Minahasa Utara?
2. Apakah sektor pertanian masih menjadi sektor basis di Kabupaten Minahasa Utara?

3. Sub-sektor pertanian apa saja yang menjadi sektor basis di Kabupaten Mihasa Utara?

\section{Tujuan}

Sesuai dengan masalah yang diuraikan maka penelitian ini bertujuan :

1. Untuk mengetahui besarnya kontribusi sektor pertanian terhadap pembangunan perekonomi di Kabupaten Minahasa Utara.

2. Untuk mengetahui apakah sektor pertanian merupakan sektor basis di Kabupaten Minahasa Utara.

3. Untuk mengetahui sub-sektor pertanian apakah yang menjadi sektor basis di Kabupaten Minahasa Utara

\section{Manfaat Penelitian}

Penelitian ini di dapat bermanfaat antara lain sebagai:

1. Bahan masukan khususnya bagi Pemerintah Kabupaten Minahasa Utara.

2. Bahan masukan dan informasi bagi mahasiswa lain yang ingin melakukan penelitian selanjutnya dalam konteks yang lebih luas dan mendalam.

\section{METODOLOGI PENELITIAN}

\section{Jenis dan Sumber Data}

Data yang digunakan dalam penelitian ini adalah data sekunder yang berupa data Produk Domestik Regional Bruto (PDRB) Kabupaten Minahasa Utara dan Provinsi Sulawesi Utara atas dasar harga konstan dari Tahun 2010 sampai dengan tahun 2015, sedangkan data sekunder dikumpulkan dari berbagai sumber antara lain kantor BPS Provinsi Sulawesi Utara, BAPPEDA, Dinas-dinas terkait lainnya.

\section{Konsep Pengukuran Variabel}

Variabel-variabel yang akan diukur dalam penelitan ini adalah sebagai berikut:

1. PDRB atas dasar harga konstan Provinsi Sulawesi Utara Tahun 2010 sampai tahun 2015.

2. PDRB atas dasar harga konstan Kabupaten Minahasa Utara Tahun 2010 sampai Tahun 2015.

3. PDRB sektor/sub sektor pertanian wilayah Kabupaten Minahasa Utara. 
4. PDRB total wilayah Kabupaten Minahasa Utara.

5. PDRB sektor/sub sektor pertanian wilayah Provinsi Sulawesi Utara. PDRB total wilayah Provinsi Sulawesi Utara.

\section{Metode Analisis Data}

\section{Analisis Location Quotient (LQ)}

Metode LQ digunakan untuk menentukan sektor basis dan sektor nonbasis yang terdapat di suatu wilayah. Menurut Tarigan (2005) metode LQ dilakukan dengan cara membandingkan porsi lapangan kerja/nilai tambah untuk sektor tertentu di wilayah kita dibandingkan dengan porsi lapangan kerja/nilai tambah untuk sektor secara nasional. Dalam bentuk rumus:

$$
\mathrm{LQ}=\frac{\mathrm{l}_{\mathrm{i}} / \mathrm{e}}{\mathrm{L}_{\mathrm{i}} / \mathrm{E}}
$$

Keterangan:

$l_{\mathrm{i}}=$ Jumlah PDRB suatu sektor kabupaten/kota

$\mathrm{e}=$ Jumlah PDRB seluruh sektor kabupaten/kota

$\mathrm{L}_{\mathrm{i}}=$ Jumlah PDRB suatu sektor tingkat provinsi $\mathrm{E}=$ Jumlah PDRB seluruh sektor tingkat provinsi

Dari rumus di atas di ketahui bahwa:

1. LQ > 1 artinya bahwa sektor tersebut merupakan sektor basis. Produk yang dihasilkan tidak hanya dapat untuk memenuhi kebutuhan di wilayah saja, tetapi juga dapat digunakan untuk memenuhi

kebutuhan wilayah lain.

2. LQ < 1 artinyabahwa sektor tersebut merupakan sektor nonbasis, karena produk yang dihasilkan tidak cukup untuk memenuhi kebutuhan di dalam wilayah.

3. $\mathrm{LQ}=1$ mempunyai arti bahwa sektor tersebut merupakan sektor nonbasis, karena produk yang dihasilkan hanya dapat memenuhi di dalam wilayah.

\section{Analisis Kontribusi Sektoral}

Kontribusi atau peranan sektor ekonomi menunjukkan struktur perekonomian yang terbentuk di suatu wilayah. Struktur ekonomi yang dinyatakan dalam persentase, menunjukkan besarnya peranan masing-masing sektor ekonomi dalam menghasilkan nilai tambah. Kontribusi sektoral ini dapat dihitung dengan menggunakan rumus:

$$
\mathrm{V}=\frac{\text { PDRB Sektor } \mathrm{i}_{\mathrm{t}}}{\text { Total PDRB }_{\mathrm{t}}} \times 100 \%
$$

Dimana:

$\mathrm{V}=$ Besarnya Kontribusi Sektoral

$\mathrm{PDRBi}_{\mathrm{t}}=$ PDRB sektor i pada tahun $\mathrm{t}$

$\mathrm{PDRB}_{\mathrm{t}}=$ Total PDRB pada tahun $\mathrm{t}$

\section{Metode Sederhana}

Menurut Hera Susanti (1995) metode ini hanya praktis digunakan untuk menghitung tingkat pertumbuhan selama satu tahun saja. Metode sederhana diformulasikan sebagai berikut:

$$
r_{(t-1, t)}=\frac{\text { PDRB }_{t}-\text { PDRB }_{t-1}}{\text { PDRB }_{t-1}} \times 100 \%
$$

Dimana :

$\mathrm{r}_{(\mathrm{t}-1, \mathrm{t})}=$ Pertumbuhan ekonomi tahunan.

PDRB $_{\mathrm{t}}=$ Produk Domestik Regional Bruto Periode $\mathrm{r}$ (berdasarkan harga berlaku).

$\mathrm{PDRB}_{\mathrm{t}-1}=$ Produk Domestik Regional Bruto tahun sebelumnya.

Untuk menghitung tingkat pertumbuhan ekonomi ekonomi untuk periode yang lebih panjang misalkan untuk 3 tahun maka tingkat pertumbuhan per tahun harus dihitung terlebih dahulu dan kemudian dirata-ratakan dengan cara berikut:

$$
r_{(t-1, t)}=\frac{r_{(t-1-t)}+r_{(t-t+1)}+r_{(t+1-t+2)}}{3}
$$

\section{Analisi Deskriptif}

Menurut Nazir (2013) metode deskriptif adalah suatu metode dalam meneliti status kelompok manusia, suatu objek, suatu set kondisi, suatu sistem pemikiran ataupun suatu kelas peristiwa pada masa sekarang. Tujuan dari penelitian deskriptif ini adalah untuk membuat deskriptif, gambaran, lukisan secara sistematik faktual dan akurat mengenai fakta-fakta sifatsifat serta hubungan antara fenomena yang diselidiki. Analisis deskriptif dalam penelitian ini bertujuan untuk memberikan gambaran atau deskripsi dari suatu data potensi ekonomi yang di peroleh dari BPS, BAPPEDA, ataupun dari instansi terkait lainnya. Gambaran atau deskripsi dalam analisis ini digunakan untuk 
mengetahui apa saja sektor-sektor yang berpotensi di Kabupaten Minahasa Utara.

\section{HASIL DAN PEMBAHASAN}

\section{Kondisi Wilayah Kabupaten Minahasa Utara}

Kabupaten Minahasa Utara adalah salah satu kabuaten yang termasuk wilayah Provinsi Sulawesi Utara. Kabupaten Minahasa Utara terletak pada koordinat antara $1^{\circ} 18^{\prime} 30^{\prime}-1^{\circ} 53^{\prime} 00^{\prime}$ ' Lintang Utara, dan $124^{\circ} 44^{\prime} 00^{\prime \prime}-125^{\circ} 11^{\prime} 00^{\prime \prime}$ Bujur Timur. Ibukota Kabupaten Minahasa Utara berjarak $35 \mathrm{Km}$ dari ibukota Propinsi Sulawesi Utara. Luas Kabupaten Minahasa Utara 1.059,24 $\mathrm{Km}^{2}$, yang terdiri dari 10 kecamatan yaitu kecamatan: Kema, Kauditan, Airmadidi, Kalawat, Dimembe, Talawaan, Wori, Likupang Barat, Likupang Timur, Likupang Selatan dapat dilihat pada Tabel 1 .

Tabel 1. Luas Wilayah Menurut Kecamatan di Kabupaten

\begin{tabular}{|c|c|c|c|}
\hline \multicolumn{4}{|c|}{ Minahasa Utara } \\
\hline No & Kecamatan & Luas Area (Km2) & Persen (\%) \\
\hline 1 & Kema & 78,76 & 7,44 \\
\hline 2 & Kauditan & 108,20 & 10,21 \\
\hline 3 & Airmadidi & 86,66 & 8,18 \\
\hline 4 & Kalawat & 39,03 & 3,68 \\
\hline 5 & Dimembe & 166,43 & 15,71 \\
\hline 6 & Talawaan & 82,51 & 7,79 \\
\hline 7 & Wori & 90,70 & 8,56 \\
\hline 8 & $\begin{array}{l}\text { Likupang } \\
\text { Barat }\end{array}$ & 104,29 & 9,85 \\
\hline 9 & $\begin{array}{l}\text { Likupang } \\
\text { Timur }\end{array}$ & 290,84 & 27,46 \\
\hline 10 & $\begin{array}{l}\text { Likupang } \\
\text { Selatan }\end{array}$ & 11,82 & 1,12 \\
\hline & $\begin{array}{l}\text { Jumlah/ } \\
\text { Total }\end{array}$ & $1.059,24$ & 100,00 \\
\hline
\end{tabular}

Tabel 1 menunjukkan bahwa posisi geografisnya Kabupaten Minahasa Utara memiliki batas-batas wilayah sebagai berikut:

Sebelah Utara :Berbatasan dengan Kabupatan Kepulauan Sitaro, Laut Sulawesi dan Laut Maluku

Sebelah Selatan :Berbatasan dengan Kabupaten Minahasa

Sebelah Timur :Berbatasan dengan Kota Bitung Sebelah Barat :Berbatasan dengan Kota Manado

Keadaan Kependudukan

Penduduk Kabupaten Minahasa Utara pada tahun 2015 tercatat sebanyak 198.084 jiwa yang terdiri dari 100.719 jiwa penduduk lakilaki dan 97.365 penduduk perempuan. Rincian jumlah penduduk dan kepadatan penduduk pada tiap kecamatan di Kabupaten Minahasa Utara dapat dilihat pada Tabel 2.

Tabel 2. Jumlah Penduduk Dan Kepadatan Penduduk Pada Tiap Kecamatan di Kabupaten Minahasa Utara Pada Tahun 2015

\begin{tabular}{|c|c|c|c|}
\hline No & Kecamatan & $\begin{array}{l}\text { Jumlah } \\
\text { Penduduk }\end{array}$ & $\begin{array}{l}\text { Kepadatan } \\
\left(\mathbf{J i w a}^{2} / \mathbf{K m}^{2}\right)\end{array}$ \\
\hline 1 & Kema & 16.486 & 209,32 \\
\hline 2 & Kauditan & 24.383 & 225,35 \\
\hline 3 & Airmadidi & 28.512 & 329.01 \\
\hline 4 & Kalawat & 30.499 & 781,42 \\
\hline 5 & Dimembe & 23.729 & 142,58 \\
\hline 6 & Talawaan & 20.493 & 248,37 \\
\hline 7 & Wori & 17.096 & 188,49 \\
\hline 8 & Likupang Barat & 16.238 & 155,70 \\
\hline 9 & $\begin{array}{l}\text { LikupangTimur } \\
\text { Likupang }\end{array}$ & 15.733 & 54,10 \\
\hline 10 & Selatan & 4.915 & 415,82 \\
\hline & $\begin{array}{l}\text { Minahasa } \\
\text { Utara }\end{array}$ & 198.084 & 187,01 \\
\hline
\end{tabular}

Berdasarkan luas wilayah dan jumlah penduduk pada Tahun 2015 maka kepadatan penduduk di Kabupaten Minahasa Utara Tahun 2015 mencapai 187 jiwa $/ \mathrm{km}^{2}$.

\section{Pendidikan}

Untuk meningkatkan mutu pendidikan tentunya diperlukan fasilitas pendidikan yang menunjang. Kabupaten Minahasa Utara memiliki fasilitas pendidikan yang cukup merata pada 10 kecamatan. Tercatat pada Tahun 2015 di Dinas Pendidikan, Pemuda dan Olahraga bahwa Kabupaten Minahasa Utara memiliki 126 Taman Kanak-Kanak, 166 Sekolah Dasar dan 94 Sekolah Menengah Pertama dan 32 Sekolah Menengah Atas.

\section{Bidang Kesehatan}

Kesehatan adalah keadaan sejahtera dari badan, jiwa, dan sosial yang memungkinkan setiap orang hidup produktif secara sosial dan ekonomis. Pembangunan kesehatan adalah bagian dari pembangunan nasional yang bertujuan untuk meningkatkan kesadaran, kemampuan, dan kemauan hidup sehat bagi setiap orang agar terwujud derajat kesehatan masyarakat yang setinggi-tingginya, pembangunan kesehatan juga sangat 
dipengaruhi oleh fasilitas kesehatan yang memadai seperti puskesmas, rumah sakit, tenaga kesehatan dan ketersediaan obat-obatan. Pada Tahun 2015 tenaga medis terbanyak di Kabupaten Minahasa Utara adalah perawat yaitu sebanyak 117 orang. Salah satu yang menjadi indikator keberhasilan di bidang kesehatan suatu daerah dapat diukur melalui tingat harapan hidup penduduknya. Angka harapan hidup di Kabupaten Minahasa Utara setiap tahun terus meningkat, data terakhir angka harapan hidup di kabupaten Minahasa Utara sebesar 70-79 Tahun.

\section{Deskripsi Produksi Sektor Pertanian}

Sektor Pertanian terdiri dari beberapa sub sektor antara yaitu :

1. Sub Sektor Tanaman Pangan

Komoditas tanaman pangan yang paling banyak di Kabupaten Minahasa Utara adalah Padi Sawah dan Jagung, pada Tahun 2015 ke dua komoditas ini memiliki nilai produksi sebesar 47.964 ton untuk Padi Sawah sedangkan untuk Jagung sebesar 20.010 ton. Komoditas Tanaman Pangan lain yang ada di Kabupaten Minahasa Utara adalah Padi Ladang, Kedelai, Kacang Tanah, Ubi Kayu Ubi Jalar dan Talas.

2. Sub Sektor Tanaman Hortikultura

Kabupaten Minahasa Utara juga memiliki produksi beberapa komoditas hortikultura. Komoditas hortikultura tanaman sayur yang paling banyak tumbuh dan terbesar merata di setiap kecamatan adalah Cabe Rawit dengan luas panen sebesar 617 hektar dengan produksi mencapai 468,7 ton pada tahun 2015. Untuk tanaman buah-buahan yang terbesar adalah Mangga dengan produksinya mencapai 2.213 ton di tahun 2015 dan Kecamatan Kema merupakan produsen buah mangga terbanyak di Kabupaten Minahasa Utara.

\section{Sub Sektor Tanaman Perkebunan}

Tanaman perkebunan yang paling banyak di Kabupaten Minahasa Utara adalah kelapa dengan luas areal perkebunan kelapa mencapai 42.763 hektar dengan produksinya mencapai 43.188 ton. Tanaman perkebunan lainnnya yang ada di Kabupaten Minahasa
Utara adalah Pala,Cengkeh, Kopi, Kakao, Jambu Mete, Aren, Jarak Pagar dan Vanili.

\section{Sub Sektor Peternakan}

Peternakan dengan potensi yang ada adalah peternakan Sapi, Kambing, Babi, Ayam Pedaging, Ayam Petelur, Ayam Buras, Itik, Burung Puyuh. Hewan ternak yang paling banyak adalah Ayam Pedaging yang mencapai 1.620 .000 ekor dan babi yang mencapai 21.614 ekor.

1. Sub Sektor Kehutanan

Untuk hutan di Kabupaten Minahasa Utara dibagi menjadi hutan cagar alam, hutan lindung, hutan bakau, hutan produksi terbatas dan hutan suaka marga satwa.

2. Sub Sektor Perikanan

Jumlah rumah tangga perikanan tangkap pada Kabupaten Minahasa Utara pada tahun 2015 mencapai 12.470 rumah tangga dan terdapat $6.191 \mathrm{kapal} / \mathrm{perahu}$, dimana 3.098 di antaranya adalah perahu dengan motor tempel. Produksi perikanan laut pada Tahun 2015 mencapai $17.672,03$ ton.

\section{Kajian Sektor Pertanian Terhadap Perekonomian di Kabupaten Minahasa Utara}

dalam pertumbuhan pembangunan perekonomian Kabupaten Minahasa Utara dan mempunyai kemampuan untuk lebih dikembangkan dalam pertumbuhan ekonomi di Kabupaten Minahasa Utara. Hal ini tergambar dalam Produk Domestik Regional Bruto (PDRB) Kabupaten Minahasa Utara yang mengalami peningkatan nilai PDRB yang cukup pesat mulai Tahun 2010-2015. Yang dapat di lihat pada Tabel 3 Produk Domestik Regional Bruto Seri 2010 Atas Dasar Harga Konstan Sektor dan Sub Sektor Pertanian Tahun 20102015 (Juta Rupiah). Tabel 3 menunjukkan bahwa sektor pertanian juga merupakan penyumbang terbesar di bandingkan sektor lain pada PDRB ADHK Tahun 2010-2015, hal ini dapat di lihat pada PDRB Seri 2010 Atas Dasar Harga Konstan Kabupaten Minahasa Utara Tahun 2010-2015. 
Tabel 3. PDRB Seri 2010 ADHK Kabupaten Minahasa Utara Sektor dan Sub Sektor Pertanian Tahun 20102015 (Juta Rupiah)

\begin{tabular}{|c|c|c|c|c|c|c|c|}
\hline & Lapangan Usaha & 2010 & 2011 & 2012 & 2013 & 2014 & 2015 \\
\hline A & $\begin{array}{l}\text { Pertanan, Kehutanan dan } \\
\text { Perikanan }\end{array}$ & $1.606 .113,4$ & $1.639 .266,8$ & $1.757 .227,9$ & $1.860 .480,4$ & $1.969 .057,4$ & $2.032 .528,2$ \\
\hline 1 & $\begin{array}{l}\text { Pertanian, Peternakan, } \\
\text { Perkebunan dan Jasa } \\
\text { Pertanian }\end{array}$ & $917.198,1$ & $910.665,3$ & $977.059,2$ & $998.146,9$ & $1.050 .723,4$ & $1.133 .186,0$ \\
\hline $\mathrm{a}$ & Tanaman Pangan & $162.749,2$ & $165.082,3$ & $164.686,6$ & $169.374,1$ & $169.149,4$ & $168.423,9$ \\
\hline b & Tanaman Holtikultura & $7.450,7$ & $8.100,1$ & $8.874,7$ & $9.518,6$ & $10.081,5$ & $10.781,8$ \\
\hline $\mathrm{c}$ & Perkebunan Semusim & 12,7 & 12,4 & 12,9 & 13,3 & 13,2 & 13,5 \\
\hline d & $\begin{array}{l}\text { Tanaman Holtikultura } \\
\text { Tahunan dan Lainnya }\end{array}$ & $86.399,8$ & $100.111,1$ & $114.306,6$ & $127.995,3$ & $132.558,1$ & $140.232,7$ \\
\hline $\mathrm{e}$ & Perkebunan Tahunan & $482.764,9$ & $443.798,0$ & $474.694,2$ & $462.702,2$ & $492.074,2$ & $541.172,8$ \\
\hline$f$ & Peternakan & $162.900,0$ & $178.674,8$ & $198.496,3$ & $212.472,8$ & $230.211,4$ & $254.724,8$ \\
\hline $\mathrm{g}$ & $\begin{array}{l}\text { Jasa Pertanian } \\
\text { Perburuan }\end{array}$ & $14.920,9$ & $14.886,7$ & $15.987,9$ & $16.070,6$ & $16.635,6$ & $17.836,5$ \\
\hline 2 & $\begin{array}{l}\text { Kehutanan } \\
\text { Penebangan Kayu }\end{array}$ & $28.624,5$ & $29.026,9$ & $30.165,3$ & $31.023,5$ & $30.256,9$ & $29.620,4$ \\
\hline 3 & Perikanan & $660.290,9$ & $699.574,6$ & $750.003,4$ & $831.310,0$ & $888.077,1$ & $869.721,9$ \\
\hline
\end{tabular}

Tabel 4. PDRB seri 2010 ADHK Kabupaten Minahasa Utara Tahun 2010-2015 (Juta Rupiah)

\begin{tabular}{|c|c|c|c|c|c|c|c|}
\hline & Lapangan Usaha & 2010 & 2011 & 2012 & 2013 & 2014 & 2015 \\
\hline 1 & $\begin{array}{l}\text { Pertanian, } \\
\text { Kehutanan, \& } \\
\text { Perikanan }\end{array}$ & $1.606 .113,4$ & $1.639 .266,8$ & $1.757 .227,9$ & $1.860 .480,4$ & $1.969 .057,4$ & $2.032 .528,2$ \\
\hline 2 & $\begin{array}{l}\text { Pertambangan } \\
\text { Penggalian }\end{array}$ & $514.338,0$ & $559.597,7$ & $601.701,1$ & $651.057,5$ & $699.281,3$ & $767.257,6$ \\
\hline 3 & Industri Pengolahan & $720.249,0$ & $777.838,8$ & $836.500,7$ & $886.961,3$ & $931.753,1$ & $983.050,0$ \\
\hline 4 & $\begin{array}{l}\text { Pengadaan Listrik \& } \\
\text { Gas }\end{array}$ & $5.244,9$ & $5.594,4$ & $6.244,4$ & $7.218,1$ & $7.958,9$ & $8.541,3$ \\
\hline 5 & $\begin{array}{l}\text { Pengadaan Air, } \\
\text { Pengelolaan } \\
\text { Sampah, } \\
\text { Limbah,Daur Ulang }\end{array}$ & $4.446,4$ & $4.722,6$ & $5.057,3$ & $5.436,8$ & $5.609,9$ & $5.779,5$ \\
\hline 6 & Konstruksi & $660.094,1$ & $726.491,1$ & $786.179,2$ & $845.631,2$ & $932.626,6$ & $1.043 .345,0$ \\
\hline 7 & $\begin{array}{l}\text { Perdagangan Besar } \\
\text { \& Eceran; Reparasi } \\
\text { Mobil \& Sepeda } \\
\text { Motor }\end{array}$ & $475.913,8$ & $523.123,3$ & $537.798,6$ & $584.956,2$ & $644.824,3$ & $692.559,0$ \\
\hline 8 & $\begin{array}{l}\text { Transportasi dan } \\
\text { Pergudangan }\end{array}$ & $209.790,2$ & $226.366,3$ & $244.457,6$ & $260.953,3$ & $284.610,9$ & $308.065,7$ \\
\hline 9 & $\begin{array}{l}\text { Penyediaan } \\
\text { Akomodasi dan } \\
\text { Makan Minum }\end{array}$ & $49.676,9$ & $53.709,8$ & $57.329,4$ & $63.066,4$ & $69.237,0$ & $75.422,2$ \\
\hline 10 & $\begin{array}{l}\text { Informasi dan } \\
\text { Komunikasi }\end{array}$ & $100.452,4$ & $105.289,3$ & $112.798,5$ & $123.191,3$ & $135.813,9$ & $149.153,0$ \\
\hline 11 & $\begin{array}{l}\text { Jasa Keuangan dan } \\
\text { Asuransi }\end{array}$ & $41.354,6$ & $44.912,9$ & $49.212,6$ & $50.959,3$ & $53.026,5$ & $55.147,4$ \\
\hline 12 & Real Estate & $272.211,0$ & $298.747,1$ & $321.703,4$ & $344.650,4$ & $379.356,2$ & $417.003,8$ \\
\hline 13 & Jasa Perusahaan & 792,2 & 866,6 & 929,7 & 993,2 & $1.081,9$ & $1.172,5$ \\
\hline 14 & $\begin{array}{l}\text { Administrasi } \\
\text { Pemerinta }\end{array}$ & $193.849,8$ & $211.266,7$ & $230.966,5$ & $246.633,3$ & $270.415,7$ & $293.466,4$ \\
\hline 15 & Jasa Pendidikan & $143.766,3$ & $156.484,5$ & $167.725,2$ & $179.222,5$ & $188.347,9$ & $204.649,2$ \\
\hline 16 & $\begin{array}{l}\text { Jasa Kesehatan dan } \\
\text { Kegiatan Sosial }\end{array}$ & $135.042,4$ & $148.234,3$ & $157.103,7$ & $167.138,5$ & $176.872,1$ & $190.923,4$ \\
\hline 17 & Jasa lainnya & $31.233,0$ & $34.484,1$ & $36.956,8$ & $39.521,2$ & $41.594,9$ & $44.840,0$ \\
\hline & Total PDRB & $5.164 .568,4$ & $5.516 .996,3$ & $5.909 .892,7$ & 6.318.070,9 & $6.791 .468,4$ & $7.272 .904,3$ \\
\hline
\end{tabular}

Sumber: BPS Minahasa Utara 2017 


\section{Kontribusi Sektor Pertanian}

Tabel 5 dapat di lihat bahwa kontribusi sektor pertanian terhadap PDRB di Kabupaten Minahasa Utara mengalami penurunan. Kontribusi sektor pertanian pada Tahun 2010 sebesar 31,0\% dan di Tahun 2011 mengalami penurunan menjadi $29,7 \%$, penurunan juga terjadi di Tahun 2012 dengan nilai kontribusi 26,7 $\%$, pada Tahun 2013 sebesar 29,4 \%, Tahun 2014 sebesar 28,9\% dan pada Tahun 2015 kontribusi sektor pertanian sebesar 27,4. Penurunan ini terjadi karena maraknya alih fingsi lahan pertanian ke non pertanian. Meskipun sektor pertanian mengalami penurunan tetapi sektor pertanian masih berperan penting dalam perekonomian di Kabupaten Minahasa Utara. Secara keseluruhan pada sub sektor Pertanian, Peternakan, Perburuan dan Jasa dalam Tahun 2010-2015 juga mengalami penurunan kontribusi, pada Tahun 2010 kontribusi dari sektor ini sebesar 57,1\% sedangkan pada Tahun 2015 kontribusinya turun menjadi 55,1\%. Pada sektor Pertanian, Peternakan, Perburuan dan jasa pertanian ini terapat sub sektor yang mengalami penurunan serta kenaikan kontribusi yaitu sub sektor tanam pangan pada periode Tahun 2010-2015 cenderung mengalami penurunan, pada tahun 2010 sub sektor ini mempunyai kontribusi sebesar 17,7\% dan pada Tahun 2011 kontribusi sub sektor sedikit meningkat menjadi $18,1 \%$, tetapi pada tahun selanjutnya mengalami penurunan hingga pada tahun 2015 nilai kontribusi sektor ini menjadi $14,8 \%$ penurunan terjadi akibat adanya alih fungsi lahan sawah, ataupun alih fungsi bercocok tanam yang semula bercocok tanam tanaman pangan beralih fungsi bercocok tanaman lain, serta pengadaan program pemerintah seperti bantuan bibit padi ladang, pengembangan padi sawah, pengembangan jagung hibrida, dinilai belum efektif sehingga belum mampu menaikan nilai kontribusi PDRB pada sub sektor ini.

Kontribusi dengan angka terkecil dalam sektor Pertanian, Peternakan, Perburuan dan Jasa ini, adalah sub sektor perkebunan semusim, pada tahun 2015 kontribusinya hanya 0,0012 \%, dan kontribusi terbesar dari sektor ini adalah sub sektor perkebunan tahunan, pada Tahun 2010 kontribusi sektor perkebunan tahunan sebesar 46,7\% dan pada Tahun 2015 kontribusi sub sektor ini sebesar $47,4 \%$, peningkatan juga di ikuti sub sektor tanaman hortikultura tahunan dan lainnya dan sub sektor peternakan. Pada Tahun 2010 kontribusi sub sektor tanaman hortikultura tahunan dan lainnya sebesar $9,41 \%$ dan pada
Tahun 2015 meningkat menjadi 11,6 \% begitu juga dengan sub sektor peternakan yang pada tahun 2010 kontribusinya sebesar $17,7 \%$ di tahun 2015 kontribusinya meningkat menjadi $20,5 \%$. Pada periode 2010 -2015 kontribusi sub sektor perikanan mengalami kenaikan, pada tahun 2010 kontibusi sub sektor perikanan sebesar $41 \%$ dan di tahun 2015 meningka menjadi 42,7 \% peningkatan ini terjadi karena keberhasilan program-program pemerintah Kabupaten Minahasa Utara seperti pengembangan bibit ikan ungul, pembinaan kelompok ekonomi masyarakat pesisir, serta pengadaan perlengkapan untuk nelayan dalam rangka meningkatkan sektor perikanan.

\section{Analisis Location Quotient (LQ) Kabupaten Minahasa Utara}

Tabel 6 dapat di lihat bahwa analisi location Quotient (LQ) ini menunjukan nilai ratarata LQ sektor pertanian dari Tahun 2010-2015 lebih dari satu (LQ > 1) dengan nilai rata-rata dalam kurun waktu 6 tahun sebesar 1,30 sehingga sektor pertanian dikatagorikan sebagai sektor basis penunjang atau sektor utama struktur ekonomi dan berpotensi eksport. Dalam sektor pertanian, sub sektor Perikanan merupakan sub sektor yang menjadi sektor basis dan berpotensi eksport dengan nilai rata-rata 1,49 artinya sub sektor perikanan pada Kabupaten Minahasa utara ini berperan lebih dominan dari pada sub sektor yang sama pada Provinsi Sulawesi Utara. Sebaliknya sub sektor kehutanan dan penebangan kayu bukan sektor basis karna dalam kurun waktu 6 tahun memiliki nilai rata-rata LQ kurang dari 1 atau lebih kecil 1 (LQ<1) yaitu sebesar 0,58. Pada sub sektor sektor Pertanian, Peternakan dan Jasa Pertanian, juga bukan merupakan sektor basis dengan angka LQ sebesar 0,82 , peran dari sub sektor ini sebagai non basis merupakan akumulasi dari ke empat sub sektor pertanian, peternakan, perburuan dan jasa pertanian yang berperan non basis, ke empat sub sektor non basis yaitu, sub sektor jasa pertanian dan perburuan pada tahun 2010 merupakan sektor basis degan nilai LQ 1,01 tetapi untuk tahun berikutnya sampai tahun 2015 LQ lebih kecil 1 (LQ<1), sehingga sektor ini menjadi non basis dengan nilai rata-rata LQ 0,96, sub sektor Tanaman Pangan dengan nilai LQ sebsar 0,61 artinya sub sektor tanaman pangan juga bukan merupakan sub sektor basisi dan tidak perpotensi eksport, di ikuti juga sub sektor Tanaman Hortikultura semusim dengan nilai ratarata LQ sebesar 0,12 dan Perkebunan Semusim 
dengan nilai rata-rata LQ sebesar 0,19 kedua sub sektor tersebut juga bukan merupakan sub sektor basis. Tetapi dalam sub sektor pertanian ini ada beberapa sub sektor yang perupakan sub sektor basis atau berpotensi eksport, atau peran dari sub sektor ini lebih dominan dibandingan dengan sub sektor yang sama pada Provinsi Sulawesi Utara yaitu masing-masing sub sektor tanaman hortikultura tahunan dan lainnya dengan nilai rata-rata LQ pada periode 2010-2015 sebesar 1,41 (LQ>1), sub sektor perkebunan tahunan dengan nilai rata-rata LQ 1,06 (LQ>1), serta sub sektor peternakan dengan nilai LQ 1,53 (LQ>1).

\section{Laju Pertumbuhan PDRB ADHK Seri 2010 Kabupaten Minahasa Utara Tahun 2010-2015}

Tabel 7 dapat di lihat pertumbuhan sektor pertanian di Kabupaten Minahasa Utara dari Tahun 2010-2015 menunjukan angka yang fluktuatif setiap Tahunnya. Pertumbuhan sektor pertanian dari Tahun 2010-2015 mempunyai angka rata-rata $4,84 \%$. Pertumbuhan sub sektor pertanian tertinggi adalah sub sektor perikanan dengan nilai $5,75 \%$ pertumbuhan sub sektor ini lebih besar dari pertumbuhan sub sektor pertanian peternakan dan jasa dengan nilai $4,34 \%$ dan pertumbuhan terendah pada PDRB Kabupaten Minahasa Utara adalah sub sektor kehutanan dan penebangan kayu dengan angka $0,72 \%$. Hal Ini terjadi karna karena Kabupaten Minahasa Utara secara geografis dekat dengan laut dan rumah tangga perikanan tangkap yang cukup besar, sementara luas lahan pertanian cenderung berkurang akibat alih fungsi lahan sehingga pertumbuhan sub sektor perikanan lebih besar dari sub sektor pertanian, peternakan, perburuan dan jasa dan sub sektor kehutanan dan penebangan kayu. Dalam sub sektor pertanian, peternakan dan jasa, sub sektor tanaman hortikultura tahunan dan lainnya memiliki nilai rata-rata tertinggi dengan angka $10,27 \%$, di ikuti dengan sub sektor perternakan dengan nilai rata-rata $9,36 \%$ dan sektor tanaman hortikultura semusim dengan nilai rata-rata $7,67 \%$. Pada sub sektor pertanian, peternakan dan jasa ini, sub sektor tanaman pangan memiliki nilai rata-rata terendah yaitu $0,69 \%$, dari data tersebut menunjukan sebagian besar penduduk yang semula menjadi petani tanaman pangan beralih profesi bertani tanaman hortikultura, baik tanaman hortikultura semusim, ataupun tanaman hortikultura tahunan.

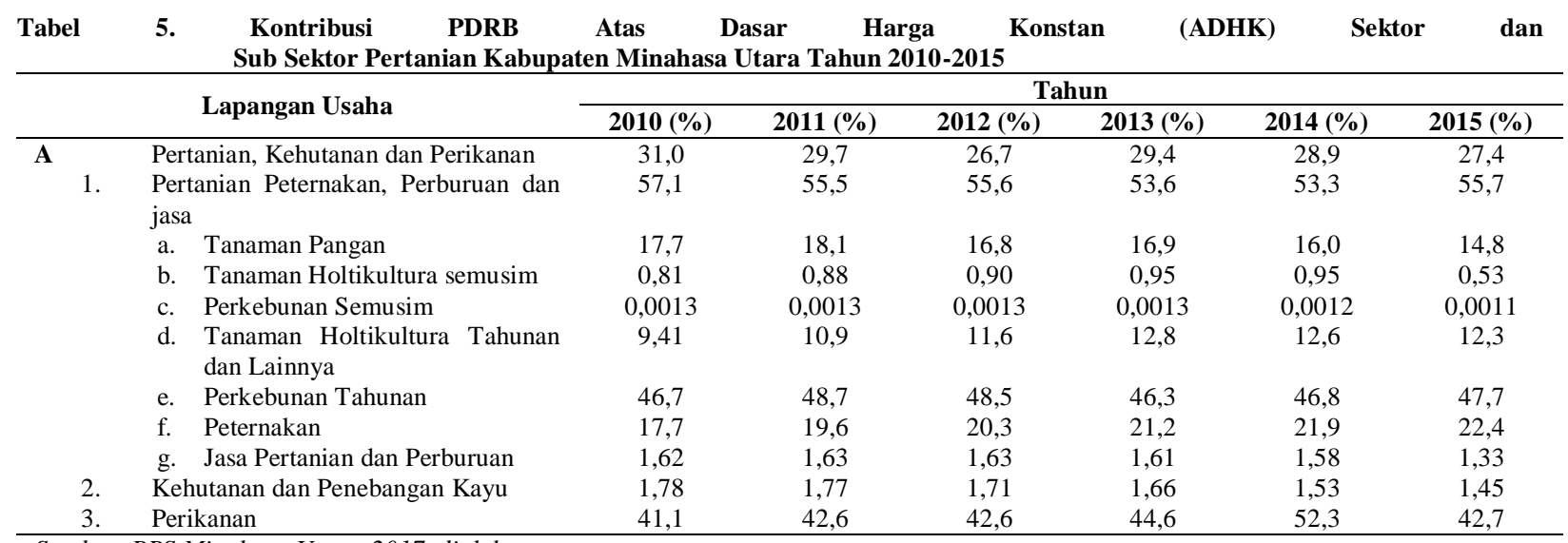

Sumber: BPS Minahasa Utara, 2017, diolah.

Tabel 6. Nilai LQ Sektor dan Sub Sektor Pertanian Kabupaten Minahasa Utara

\begin{tabular}{|c|c|c|c|c|c|c|c|c|}
\hline \multirow{2}{*}{\multicolumn{2}{|c|}{ Lapangan Usaha }} & \multicolumn{6}{|c|}{ LQ } & \multirow[t]{2}{*}{ Rata-rata } \\
\hline & & 2010 & 2011 & 2012 & 2013 & 2014 & 2015 & \\
\hline \multirow[t]{10}{*}{$\mathbf{A}$} & Pertanian Kehutanan dan Perikanan & 1,34 & 1,31 & 1,18 & 1,31 & 1,33 & 1,35 & 1.30 \\
\hline & Pertanian Peternakan, Perburuan dan jasa & 0,83 & 0,83 & 0,83 & 0,81 & 0,82 & 0,83 & 0,82 \\
\hline & a. Tanaman Pangan & 0,58 & 0,64 & 0,61 & 0,61 & 0,64 & 0,60 & 0,61 \\
\hline & b. Tanaman Hortikultura semusim & 0,13 & 0,17 & 0,13 & 0,13 & 0,13 & 0,07 & 0,12 \\
\hline & c. Perkebunan Semusim & 0,16 & 0,25 & 0,16 & 0,27 & 0,16 & 015 & 0,19 \\
\hline & d. Tanaman Hortikultura Tahunan dan Lainnya & 1,42 & 1,33 & 1,39 & 1,44 & 1,44 & 1,46 & 1,41 \\
\hline & e. Perkebunan Tahunan & 0,93 & 1,17 & 1,14 & 1,06 & 1,06 & 1,04 & 1,06 \\
\hline & f. Peternakan & 1,54 & 1,46 & 1,53 & 1,61 & 1,50 & 1,57 & 1,53 \\
\hline & g. Jasa Pertanian dan Perburuan & 1.01 & 0,99 & 0,98 & 0,98 & 0,98 & 0,82 & 0,96 \\
\hline & Kehutanan dan Penebangan Kayu & 0,56 & 0,58 & 0,60 & 0,59 & 0,60 & 0,58 & 0,58 \\
\hline 3. & Perikanan & 1,01 & 1,40 & 1,35 & 1,41 & 1,62 & 1,40 & 1,49 \\
\hline
\end{tabular}

Sumber: BPS Minahasa Utara, 2017 (Tahun 2010-2015), diolah. 
Tabel 7. Pertumbuhan PDRB Sektor dan Sub Sektor Pertanian Kabupaten Minahasa Utara Tahun 2010 - 2015

\begin{tabular}{|c|c|c|c|c|c|c|c|}
\hline & \multirow{2}{*}{ Lapangan Usaha } & \multicolumn{3}{|c|}{ Tahun } & \multicolumn{2}{|c|}{ Rata- rata } & \multirow[b]{2}{*}{$(\%)$} \\
\hline & & $\begin{array}{c}2010-2011 \\
(\%)\end{array}$ & $\begin{array}{c}2011-2012 \\
(\%)\end{array}$ & $\begin{array}{c}2012-2013 \\
(\%)\end{array}$ & $\begin{array}{c}2013-2014 \\
(\%)\end{array}$ & $\begin{array}{c}\text { 2014-2015 } \\
(\%)\end{array}$ & \\
\hline \multirow[t]{9}{*}{$\mathbf{A}$} & $\begin{array}{lll}\text { Pertanian } & \text { Kehutanan } \\
\text { Perikanan } & & \\
\end{array}$ & 2,06 & 7,20 & 5,88 & 5,84 & 3,22 & 4,84 \\
\hline & $\begin{array}{l}\text { Pertanian Peternakan, } \\
\text { Perburuan dan jasa }\end{array}$ & $-0,71$ & 7,29 & 2,16 & 5,27 & 7,85 & 4,34 \\
\hline & a. Tanaman Pangan & 1,43 & $-0,24$ & 2,85 & $-0,13$ & $-0,43$ & 0,69 \\
\hline & $\begin{array}{l}\text { b. Tanaman } \\
\text { semusim }\end{array}$ Holtikultura & 8,71 & 9,56 & 7,26 & 5,91 & 6,95 & 7,67 \\
\hline & c. Perkebunan Semusim & $-2,36$ & 4,03 & 3,10 & $-0,75$ & 2,27 & 2,45 \\
\hline & $\begin{array}{l}\text { d. Tanaman Holtikultura } \\
\text { Tahunan dan Lainnya }\end{array}$ & 15,86 & 14,17 & 11,98 & 3,56 & 5,79 & $\begin{array}{l}10,2 \\
7\end{array}$ \\
\hline & e. Perkebunan Tahunan & $-8,07$ & 6,96 & $-2,53$ & 6,35 & 9,98 & 2,53 \\
\hline & f. Peternakan & 9,68 & 11,09 & 7,04 & 8,35 & 10,65 & 9,36 \\
\hline & $\begin{array}{l}\text { g. Jasa Pertanian dan } \\
\text { Perburuan }\end{array}$ & $-0,22$ & 7,39 & 0,52 & 3,52 & 7,22 & 3,68 \\
\hline 2. & $\begin{array}{l}\text { Kehutanan dan Penebangan } \\
\text { Kayu }\end{array}$ & 1,41 & 3,92 & 2,85 & $-2,47$ & $-2,10$ & 0,72 \\
\hline 3. & Perikanan & 5,95 & 7,21 & 10,68 & 6,83 & $-2,07$ & 5,75 \\
\hline
\end{tabular}

\section{KESIMPULAN DAN SARAN}

\section{Kesimpulan}

Kontribusi sektor pertanian di Kabupaten Minahasa Utara mengalami penurunan, pada Tahun 2010 kontribusi sektor pertanian sebesar $31,0 \%$ dan pada Tahun 2015 turun menjadi 27,4\%. Pertumbuhan rata-rata sektor pertanian di Kabupaten Minahasa Utara pada Tahun 20102015 sebesar 4,84 \%. Nilai PDRB sektor pertanian Kabupaten Minahasa Utara dalam kurun waktu Tahun 2010-2015 mengalami kecenderung meningkat. Dan analisis Location Quotinet (LQ) dalam kurun waktu 6 Tahun (2010-2015) sektor pertaninan merupakan sektor basis di Kabupaten Minahasa Utara dengan nilai rata-rata LQ 1,30. Serta sub sektor pertanian yang termasuk dalam katagori sub sektor pertanian basis pada periode 2010-2015 adalah sub sektor perikanan dengan nilai rata-rata LQ 1,49, sub sektor hortikultura tahunan LQ 1,41 , sub sektor perkebunan tahunan dengan nilai rata-rata LQ 1,06, dan sub sektor peternakan dengan nilai rata-rata LQ 1,53.

\section{Saran}

Sebagai sektor basis dan kontribusi terbesar pada PDRB di Kabupatan Minahasa Utara maka sektor pertanian harus mendapat perhatian khusus dari pemerintah Kabupaten Minahasa Utara untuk dapat terus di kembangkan sehingga dengan majunya sektor pertanian tentunya dapat mendorong pertumbuhan sektor lain. Dan dalam upaya peningkatan sektor pertanian dalam pembangunan perekonomian di Kabupaten Minahasa Utara, Pemerintah Kabupaten Minahasa Utara memprioritaskan sub sektor pertanian unggulan (sub sektor perikanan, Sub Sektor Tanaman Hortikultura Tahunan dan lainnya, Sub Sektor Tanaman Perkebunan dan Sub Sektor Peternakan) karena sangat potensial untuk lebih dikembangkan sehingga akan dapat meningkatakan kontribusi terhadap PDRB Kabupaten Minahasa Utara. Serta pemerintah juga perlu perhatian khusus pada sub sektor yang memiliki pertumbuhan lambat, dengan upaya dapat mendorong pertumbuhan sub sektor yang memiliki pertumbuhan rendah, seperti mengoptimalkan penyuluh pertanian untuk mendorong peningakatan produktifitas hasil pertaninan dari masing-masing sub sektor, sehingga nantinya sektor pertanian dapat meningakat serta kontribusi pada PDRB Kabupaten Minahasa Utara juga mengalami peningkatan. 


\section{DAFTAR PUSTAKA}

Adisasmita, Rahardjo. 2005. Dasar-Dasar Ekonomi Wilayah. Graha Ilmu. Jakarta.

Adisasmita, Rahardjo. 2008.Pengembangan Wilayah Konsep Dan Teori. Penerbit Graha Ilmu. Jakarta

Ambardi, Urbanus $M$ dan Socia Prihawantoro. 2002. Pengembangan Wilayah dan Otonomi Daerah. Pusat Pengkajian Pengembangan Wilayah (P2KTPW - BPPT). Jakarta.

Badan Pusat Statistik. 2017. Minahasa Utara Dalam Angka . BPS Provinsi Sulawesi Utara. Manado.

Badan Pusat Statistik. 2017. Produk Domestik Regional Bruto Kabupaten Minahasa Utara Tahun 2010-2015. BPS Kabupaten Minahasa Utara. Airmadidi.

Buduharsono, S. 2001. Teknik Pengembangan Wilayah Pesisir dan Lautan. Pradnya Pramita. Jakarta.

Geraldo, P. 2015. Peranan Sektor Pertanian Di Kabupaten Minahasa Tenggara. Skripsi Fakultas Pertanian. UNSRAT. Manado.

Hera Susanti, Moh. Ikhasan, Widyanti.1995. Indikator Indikator Makro Ekonomi. Fakultas Ekonomi Universitas Indonesia.

Muhammad, G. 2008. Analisis Pembangunan Wilayah Berbasis Sektor Unggulan Kabupaten Lamongan Provinsi Jawa Timur. Skripsi.Fakultas Pertanian. IPB. Bogor.

Nazir, Moh. 2013. Metode Penelitian.Balai Aksara. Jakarta.
Neni Woyanti. 2008. Analisis Sektor Potensial dan Pengembangan Wilayah Guna Mendorong Pembangunan Di Kabupaten Rembang. Skripsi. Fakultas Ekonomi. UNDIP. Semarang.

Nuraini, Ida, 2005. Pengantar Ekonomi Mikro, Malang : Penerbit UMM.

Riyadi, D. S. 2005. Dampak Globalisasi Ekonomi dan Kebijakan Regionalisasi Terhadap Pengembangan Wilayah Indonesia.Pusat pengkajian kebijakan pengembangan wilayah (P2KTPW BPPT). Jakarta.

Rustiadi, Ernan. 2006. Perencanaan dan Pengembangan Wilayah, edisi Mei 2006 Fakultas Pertanian, IPB, Bogor.

Rustiadi, Ernan; Saefulhakim, Susun dan Dayah R. Panuju. 2011. Perencanaan dan Pengembangan Wilayah. Crespent Pres dan Yayasan Pustaka Obor Indonesia, Jakarta.

Santoso, J. 2005. Analisis Peran Sektor Pertanian Dalam Pembangunan Wilayah Di Kabupaten Boyolali. Skripsi. Fakultas Pertanian. IPB. Bogor.

Sukirno, Sadono, 2002. Makroekonomi Moderen. Raja Grafindo Persada, Jakarta.

Sukirno, Sadono, 2005. Mikro Ekonomi Teori Pengantar. Raja Grafindo Persada, Jakarta.

Suparmoko, M. 2002. Ekonomo Publik,Untuk Keuangan dan Pembangunan Daerah. Andi. Yogyakarta.

Tadaro M.P 2006. Pembangunan Ekonomi Dunia Ketiga Penerbit Erlangga, Jakarta. 
Tarigan, R. 2002. Perencanaan Pembangunan Wilayah. Pendekatan Ekonomi dan Ruang. Direktorat Jendral Pendidikan Tinggi Departemen Pendidikan Nasional. Medan.

Tarigan, R. 2005. Perencanaan Pembangunan Wilayah. Bumi Aksara. Jakarta.

Usya Nurlatifa. 2006. Analisis Struktur Ekonomi dan Identifikasi Sektor Unggulan Di Kabupaten Subang. Skripsi. Fakultas Ekonomi Dan Menejemen. IPB. Bogor. 